\title{
ON THE ETERNITY OF THE WORLD
}





\title{
JOHN PECHAM \\ QUESTIONS CONCERNING THE ETERNITY OF THE WORLD
}

\author{
Translated by \\ Vincent G. PotTeR, S.J.
}

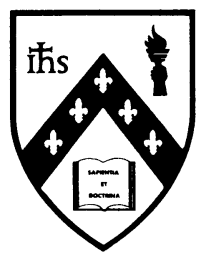

Fordham University Press

New York 
(C) Copyright 1993 Fordham University Press

All rights reserved

LC-93-26602

ISBN 0-8232-1488-5 (clothbound)

Library of Congress Cataloging-in-Publication Data

Peckham, John, d. 1292.

(De aeternitate mundi. English \& Latin)

Questions concerning the eternity of the world / John Pecham;

translated by Vincent $\mathrm{G}$. Potter.

p. $\mathrm{cm}$.

Includes bibliographical references.

ISBN 0-8232-1488-5 : \$25.00

1. Cosmology-Early works to 1800 . 2. Eternity-Early works to 1800 .

3. Creation-Early works to 1800 . 4. Infinity-Early works to 1800 .

I. Potter, Vincent G. II. Title.

B765.P43D4313 1993

$113-\mathrm{dc} 20$

93-26602

CIP

The Latin text and notes and the description of the manuscripts are reproduced from Ignatius Brady, "John Pecham and the Background of Aquinas's De aeternitate mundi," in St. Thomas Aquinas, 1274-1974: Commemorative Studies II, ed. Armand A. Maurer, C.S.B., 2 vols. (Toronto: Pontifical Institute of Mediaeval Studies, 1974), pp. 155-78. Copyright $\odot 1974$ by the Pontifical Institute of Mediaeval Studies, Toronto. 